\title{
歯科保存学領域へのレーザー応用一その可 能性を考える
}

\section{Application of laser in restorative den- tistory, endodontology and periodontology}

\author{
庄司茂 \\ Shigeru SHOJI
}

東北大学歯学部菌科保存学第 1 講座

厂980 仙台市星陵町 4-1

$022-274-1111$ (3254)

\begin{abstract}
Department of endodontics and periodontics, Tohoku University, School of Dentistry, 4-1 Seiryo-machi, Sendai, 980 JAPAN
\end{abstract}

\section{総説}

Maiman が 1960 年にルビーレーザーの発振に始めて 成功した。その装年には,レーザー光は, 眼科領域で,

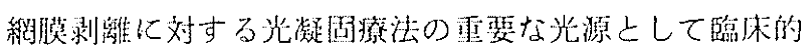
に位涫づけら机，現在に至っている。まだ、レーザーメ スとして $\mathrm{CO}_{2} レ$ レ゙ーや $\mathrm{Nd}$ : YAG レーザーが, 電 父メスとの併用などにより，一応の評倾を得ている。そ して、アルゴンレーザー光とへマトポルフィリンによる 癌光化学治療など，癌代対する診断・治療がレーザ一光 の叮能性として，医科において注目されている。

一方，霜科に执てては，1964年に Goldman が，レ ーザー光の加工性に着目し，ルビーレーザー光の focused beam でエナメル質に穴をあけ，レーザー光に上る 䆛洞形成の可能性に大きな期街が撕けられた。しかし， レーザー光を狭い口腔内に導光する技術的問題や，エナ メル質や象牙質を玥成する際の出力のコントロールが難 しいとと，そして，高法加対する安全性など，多くの 問題をかかえていることが, 種々の奏験を進めていく過 程で判明しレーザ一光に上る窝洞坆成は実現しなかっ た。しかし，1964年，Sternがヒ卜拔去雨のエナメル斯 に，ルビー・レーザーを照射し酎酸性が问上することを

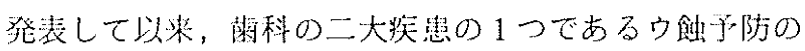

大きな武器になるのではないかと考えられた。その後，单

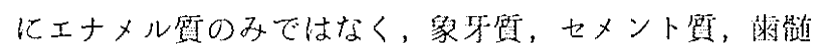

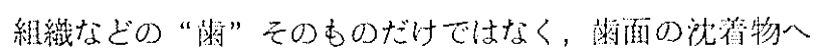
の照射など，レーザー光の䕰科的応用の可能性二の探求 が，Goldman 以来23年閳にたたって行わ机てきた。

ここでは，乙れまでの研究に対し，憐科保存学領域へ の臨床応用の可能性:の有掑を，実際の治澄室での実用を

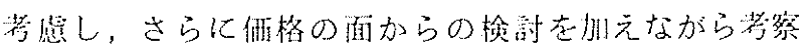
してみた。

\section{I. 保存修復学領域}

レーザー光による简洞形成は実用化さ扎なかった。従 って，琴在臨床応用が考えられる分野としてフィッシャ 一・シーラントと充垻物の迅縁封鎖の二つが若えられる。 (i) フィッシャー・シーラント

1966 年に炭酸ガスレーザーを用いてエナメル質の酎酸 性の问、をはかったStern \& Sognnaes'占以来，日本で も Nd－YAG レーザーを中心として，山本 ${ }^{2)}$ や森附 ${ }^{3)}$

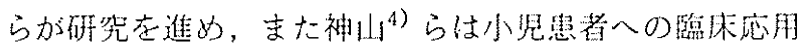
老行っている。彼らは，エナメル唭表田に、レーザー光 の服収を目的として黑色剂を整布した後にレーザー光

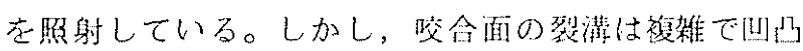


があり，しかむ， $2 \mathrm{~mm}$ 前後の梁さがあるため，光である レーザー光が到達できない部位も生じる。

一方, フィッシャーシーライト材としては，現在グラ スアイオノマーセメントと，流動性の良いコンポジット レジンが用いられている。特に、コンポジットレジンは 最近のエッチング剤やボンディング剂の発達でエナメル 質との接着性が飛躍的に向上してきているため，フィッ シャーシーラント材としてその教果が期待でき，俩格や 操作性そして保険に適用されているととから，広く臨床 応用されている。ただ，レジンやセメントを填塞する前 にも，咬合面の小简裂湿をでラシコーンなどで清掃する が，完全には沈着物(微生物を含む)を除去できない。乙 のととは、レジンやセメントの下でのウ蝕の発生を引き 起こす可能性がある。

樑達性のレーザ一光によって，乙れまでレーザー照射 によって得られてきた酎酸性问上の効果に加え，小窝裂

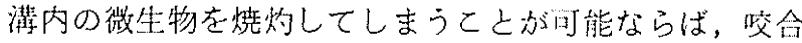
面ウ蝕や隣接面恡の防止にも役立つと瑟われる。現在 用いられている $\mathrm{Nd}: \mathrm{YAG} レ$ レ゙ーでは讨力 $10 \mathrm{~W}$ ，照 射時間 $0.6 〜 0.8$ 秒と高エネルギーであるため高洒となり， ため，レーザー光発生装置す一千万阿以上であるため，

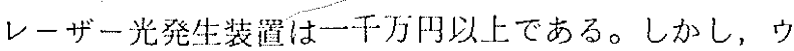
蝕予防效果，操作性そして安全性が確主されれば，三才 児へのサホライド梁布と同樣に，各保隃所での乳㴹への レーザー照射，学校检㟝での奶若永久潾へのレーザー 照射なよ゙と，使用台数が增加すれば，発生装睢の低価格 化は十分可能と考えられる。

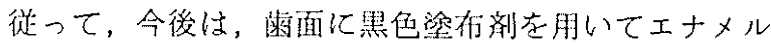
質表湎にのみ酎酸性を付与するのではなく，エナメル質 内部にも変化を生じさせ酎酸性が问上するような，哚達性 のあるレーザーの探究・開発が必要なのではないかと想 われる。

\section{(ii)充填物の辺緣封鎖}

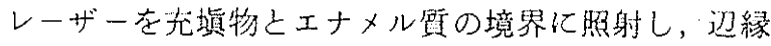
封鎖性を向上させるとともに，エナメル質にも嘖酸性を 付与し，二次う䶿の発生を防止しようと，程々の研究が 行われている。

充塡材として，金属(金合金やアマルガム)は，レーザ 一が光であることから，補綴領域でのレーザー溶接と椺

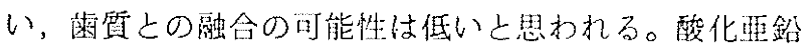
やケイ酸塩を主成分とするセメント類む橉質との融合は 考えられない。

現在，鼠も期待されるのはレジンで，特に光霆合型コ ンポジットレジンである。この種のレジンは，最近特に

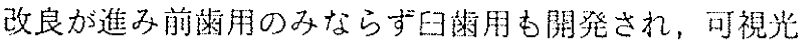

線重合型レジンが広く臨床応用されている。このレジン の光増感剂として，473nmに吸収ピークを持つ $\mathrm{dl}$-力 ンファーキノンが用いられている。 $\mathrm{dl}$-カンファーキノ ンは $430 \mathrm{~nm}$ から $490 \mathrm{~nm}$ にのみ吸収を示すので，それ 以外の波長は硬化に役亡たない。

この波長域で発振するレーザーとして，久光5)らは， 窒素励起色素レーザーを用いて，レーザー照射によるレ ジンの硬化深度を测定し，充分臨床応用可能な潹度が得 られている。

従って、レーザーによる辺縁封銷の可能性を有するレ ジンとしては，

(1)あらゆる波長のレーザー光を吸収する黒色系のレジ ン

(2) $\mathrm{dl}$ ーカンファーキノンなよ゙の，特定の吸収域を示す 光増感剤を含むレジン

の 2 種類が考えられる。

黒色系のレジンは，あらゆるレーザーに及応すると思 われるが，エナメル質に耐酸性を与える程のレーザ一を 照射すれば，かなりの就が発生し，レジンそのものの物 性が劣化すると考えられる。

空素励起色秦レーザーを用いた久光らは，その出打が $300 \sim 700 \mathrm{~mW}$ と低出力であったため，レジンの硬化は 十分であったが，エナメル質への耐酸性の付与は期街で きない。ただ，我々6)の行った実験で，化学重合型レジ ンではあったが, $10 \mathrm{~J} / \mathrm{cm}^{2}$ ( $10 \mathrm{~W}-0.1$ 秒間: defocuse) でレジンにはとんど変化を与えず，耐酸性を与えると とができたととから，今後， $\mathrm{dl}$ ーカンフォーキノン以外 の光增感剂が開発されれば，エナメル質に耐酸性を付与 可能なレーザーも閵発されると思われる。

\section{II. 柬内療法学領域}

対象とするものが，エナメル質や象牙質などの硬組織

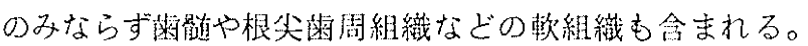
レーザーが生体化作用する様式として光化学的作用, 電 磁的作用そして熱作用の3 種が関係すると想われる。

この領域では，菊の消みの発生で大きな比重を占める

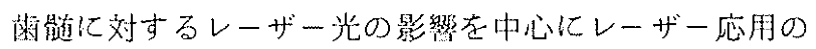
问能性を䒬えてみたい。

(i)碀骾組織

\section{イ。治獾促進(修復象牙䐝の形成)}

低出力のアルゴンレーザーや炭酸ガスレーザー照射に

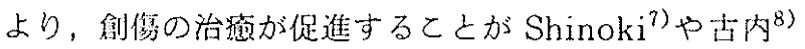

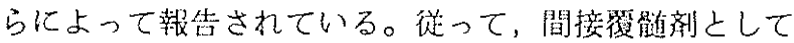
現在用いられている，酸化㱟鉛一ュージノールセメント に変えてレーザーを照射すると，修復象䪵が形成さ 
れることは十分考えられる。このことは，辰濢9)が，ア

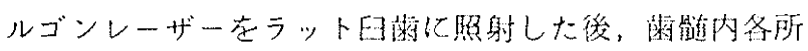
に二次象牙質の形成が胃られ数ヶ月のうちに画鹤内を 完全に埋めつくすよ報告している。さらに進めて考える

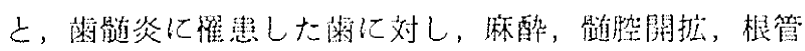
拡大そして根管光填などといった繁雑な処篗を行わずに

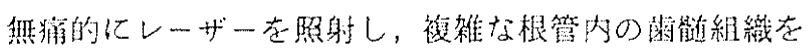
石灭化させ得る问能性がある。

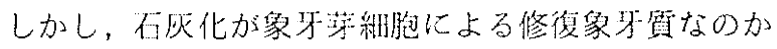

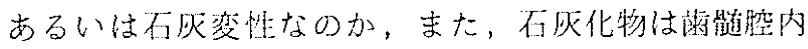
老完全に埋めつくし残䯠炎が生じる四能性がないのか などまだ研究されなりればならない閏題が残されてお り，従来の少法に取って変わるまでには多くの時閫が 必刑之瑟扣れる。

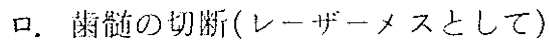

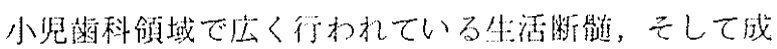

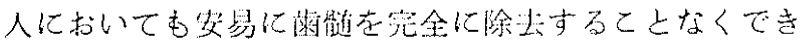
るだけ残すととを目的とした值接得蹎が注目集めてい

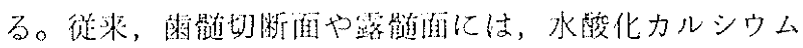

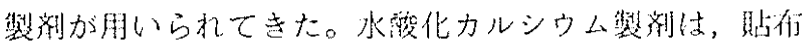
部位に dentin bridge 在䛋成するなよ゙の利点がする。し

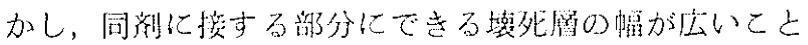

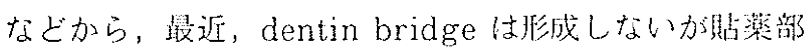

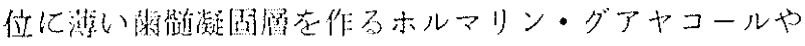
グルタールアルデヒドが堙风床朋されている。

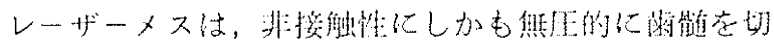
断(本体細織の㠜国)できる。我々 ${ }^{10)}$ は赫般ガスレーザー 存，松本"11) らはNd:YAGレーザー字网いて砸究在行

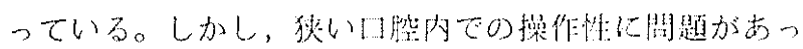

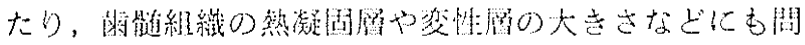

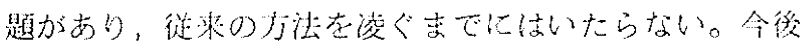
四能性が残されているのは，ファイバー(まだ閏発途中)

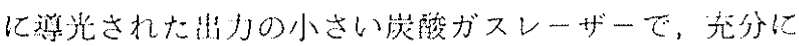
照射落絞れるむのが待たれる。

\section{八. 根管治港}

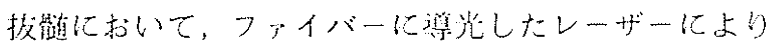

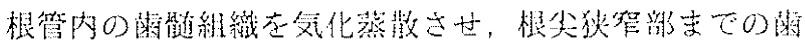

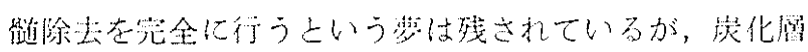

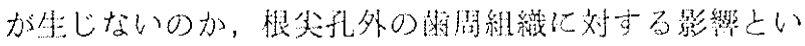

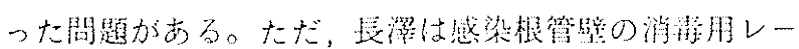

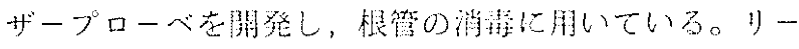
ミングやファイソングの消洊㭕として，レー+゙ーは炎で あるためその到達性で，ボルマリン・クレゾールなどの ガス性のものに少るのではないか上等えられる。

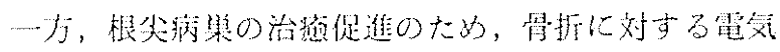

治療と同㥞に，レーザーの電磁作用による磁場を形成し 造骨機能の促進を計る研呪すある。しかし根管内が完全 に根管充塂可能ならレーザ一照射は必要ないと思われる。 二. 鎮削效果 (象牙質知覚過敏症に対し)

レーザー照射による鎮狱効果について，松本らや西山12) が報告している。適応症しされている中です，象牙質知 覚過敏症は確実な治療法が見出されていないため，切削 などの処㛭を必要とせず，ただ患部付近にレーザーを照 射するだけの治療法は，臨休家にも注目されている。し 加し，象牙斦知覚過敏症は実験的に惹起できず，しかも， 疼捔の感じうは個体差が大きい。従って，ての種の研究 では多くの症例数とともに，ダブル・ブラインドテスト が絶対汇必要である。

我々は， GaAlAs 半筫体レーザー $(30 \mathrm{~mW})$ とともに， 皱第䓄知筧過敏症に効果を有すると思われる $\mathrm{He}-\mathrm{Ne} レ$ ーザー $(5 \mathrm{~mW})$ を用いて偟床奏験を行った。ダブルブラ インドテストで行うために2つのマニュプレーターのう

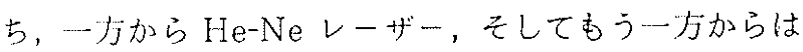
He-Ne レーザーと同じ赤色光が発生する装䇠を用いた。 间，発光中は闻者ともブザーが瞗り続ける。照射は，60 秒阔で 2 回連続で行った。 た。

捯例数が16例( $\mathrm{He}-\mathrm{Ne}: 10$ 例，プラセボ：6例）亡少 いが，He-Neレーザーを照射した症例では3例で著 効走示し，留效は1例ではとんどの症例で症状の改善が 見られた。一すフプラセボでは著効例は見られなかった むのの半数で症状の改楿が見られた。このととから， 一般の人のレーザー光＝魔法の光といった認識や，ブザ 一の発振音, 担当医の治港努力への信頼や感謝といった

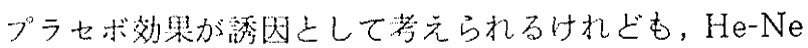

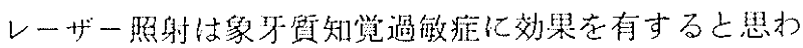
れる。

この理目としては，松本らは，レーザー照射によって 生じる電磁波が神経線維の膜の透過科:関与する $\mathrm{K}+ゃ$ $\mathrm{Na}^{+}$のイオン挢過性に影茈を与えることにより，神経

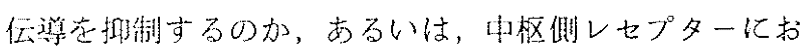

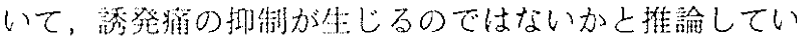
る。ただ，GaAlAs 半質体レーザーを植接坐骨神経に

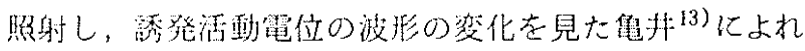
ば，半㮆体レーザー照射では変化は見られなかった。ま

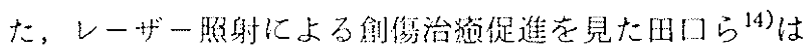

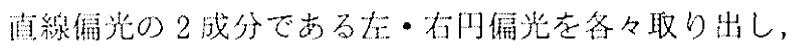

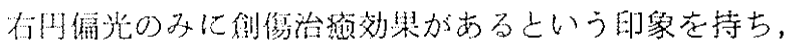

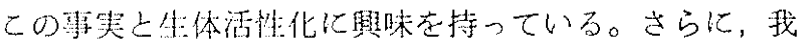
々の行ったHe-Neレーザーに上る皱牙質知覚過敏症人 
の照射において，著効を示した 3 例のうち 2 例で，軽い 温感を訴えているととや，効果の発現が速いと之，そし て, Arndt-Schulz の法則「生体に与えられた刺激は， 弱ければ生体の生理反応を助長し，强い刺激は生体反応 を抑制し，過度の刺激は生体反応を停止される」などを 若えあわせると，少くともレーザ一照射による象牙質知 覚過敏症住対する効果の作用機序として，レーザーによ る照射部位のわずかな温度、上昇，あるいは，電磁作用 に上る象牙芽緗胞そのむのへの加温などによって生じた 象牙芽細胞の形態的变化による，象牙緗管内液の移動の 移動につながったのではないかと思われる。まだ，作 用機序は判明していないが，乙の分野の研究は與味ある あのであり更なる発展が望まれる。

ホ. 消毒(リーマーなどの小器具)

芽胞を形成する耐熟性細菌が付鿓したリーマーに対し 10Wの炭酸ガスレーザーを 3 秒間照射したHooks ${ }^{15)} ら$ の研究では, 細藏は完全に死堿した。この理由として, 遠赤外線と茌体との反応に上って生じる熱による薄接的 作用が考えられる。

従って，最近関心か高まっている，肝炎やエイズなど のウィルスを含んだ血液や啗液が付着したバーやリーマ 一の消毒法として，柳格の面を除けば非常に簡便で確実 な方法ではないかと思われる。

\section{II. 齿周病学領域}

\section{1. 朄面沈着物の除去}

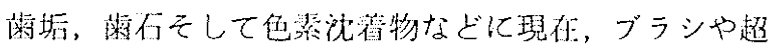
音波スケーラーそして酸化唓敛などの吹付け除去器など

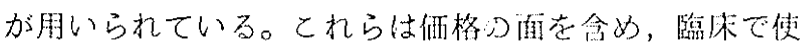

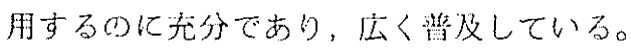

レーザーによる雨石除去などは経費の面で問題となる が，縁上闲石はレーザー照射によりエナメル貿表面から

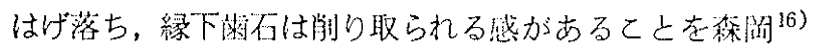
らは栕告している。

ロ. 䍀患セメント質への応用

碀周突患の治療，特に濑肉剥離怪爬術などの手術後に

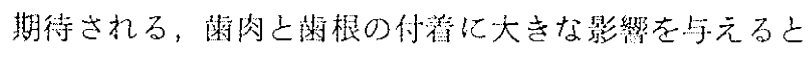

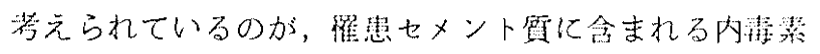
(エンドトキシン)である。この翟慗はセメント筫表層 3 分の1にしかないととや，セメント質はできるだけ残し た力が再付着に良いと考えら机，刚先の鈍ったスケーラ 一で根面をルート・プレーニングすることが考えられて いる。間世田 ${ }^{17)} ら は ， 30 \mathrm{~J} / \mathrm{cm}^{2}$ の Nd：YAGレーザー を照射することにより，エンドトキシンを不活化できる てとを報告している。
縁下獭石と同様に、レーザー照射により程患セメント 質を一層削除でき，エンドトキシンを不活化できるなら 歯周治療における重要な治療法となり得石可能性がある。 ただ、レーザー照射により，セメント質中の有機質の燒 失や，ハイドロキシアパタイトの結晶の変化が，付着に どの様な影響を与えるかなどの研究が今後必要と思われ る。

\section{N. まとめ}

1980 年に東京で開かれた第一回日本レーザー医学会で の参加者の熟気は，大学関係者のみならず企業人にも 感じられ、レーザー応用の領域が船限に広がっているよ うに思えた。

しかし, 厘々の研究が進むにつれて、レーザー応用法 が, 従徕の方法に比較して, 効果, 操作性そして揀格な どの面で問題を有しているととが判明してきた。ただ， 光颜業振興会が昭和62年 5 月20日に発表した，レーザー

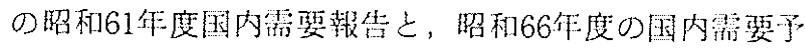
想を見てみると，医用レーザー装㽞で眼科用レーザー治

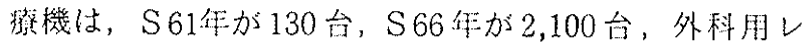
ーザー治㙩機はS 61 年が 85 台，S66年が 1,700 台，内科 用レーザー治療機は，S61 年が 40 台，S66年が 200 台上 見込ま机ている。

このととからも解るように，䋛科においても医科同様 急激な発展は裂めないか，曼を描きながら，其礎的な研 究を著実に䘕っていく必耍があると䍐われる。

\section{文献}

1. Stern, R.H., Sognnaes, R.F., Goodman, F.: Laser effect on in vitro enamel permeability and solubility, J.A.D.A., $73: 838-$ 843, 1966.

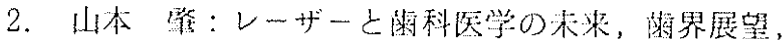
$68: 167-170,1986$.

3. 森阔俊夫，鈴木和雄：レーザーに上る葽触予防(上)， 蒌界展望，62：529-537， 1983.

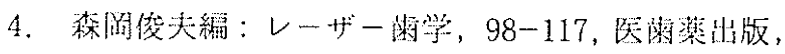
1986.

5. 久光 久: レジン重合詡可視光線照射器, 獭科ジャ ーナル，25:471-487, 1987.

6. Shoji, S. et. al. : Change of boundary between dental enamel and restorative materials caused by Nd:YAG laser irradiation, J. Jap. Soc. Laser Med., 4:265-266, 1984. 
7. Shinoki, K. et. al. : Application of low output laser to the adhesion of skin, J. Jap. Soc. Laser Med., 4:185-186, 1984.

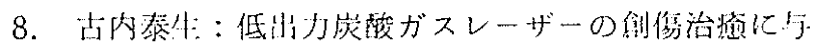

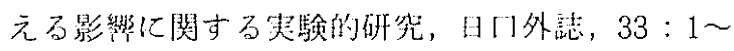
13, 1987.

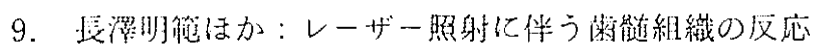

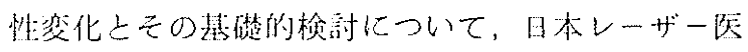
学会誌, $5: 413-416,1985$.

10. Shoji, S., Nakamura, M., Horiuchi, H. : Histopathological changes in dental pulps irradiated by $\mathrm{CO}_{2}$ laser; a preliminary report on laser pulpotomy, J. Endodont., $11: 379-384,1985$.

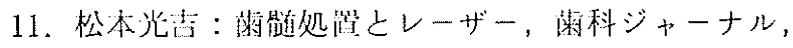
$25: 489-497,1987$.

12. 西山俊夫：ソフトレーザーの朄科的応用之問題点，

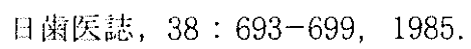

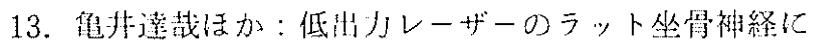

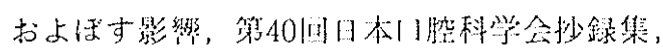
1986.

14. 田口喜婎ら：低出力レーザーの医学応用, BME， $1: 518-522,1987$.

15. Hooks, W.T. et. al. : Use of the carbon dioxide laser in sterilization of endodontics reamers, Oral Surg., 49:263-265, 1980.

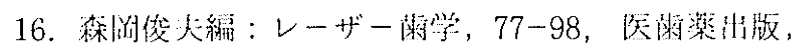
1986.

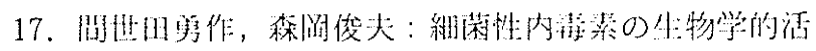
性に対するNd-YAGレーザーの影恝について， 日本丁腔街生学会九州地方会, 宮崳(1985)。 